\title{
Audit Fees for the Segments of Non-Listed Auditees in Slovenia
}

\section{Stager $\mathbf{V}^{\star 1}$, Marjan Odar ${ }^{2}$}

${ }^{1}$ Faculty of Economics and Business, University of Maribor, Maribor, Slovenia

${ }^{2}$ Faculty of Economics, University of Ljubljana, Kardeljeva ploscad 17, 1000 Ljubljana, Slovenia

\begin{abstract}
In Slovenia, no auditing company has any dominant influence. Small auditing companies started to decrease audit fees a few years ago, which triggered a spiral of falling audit fees. The argument stated that auditors should not accept very low audit fees due to competition for business. Competing with the audit fee is limited because it can impair auditor independence and reduce the quality of auditing services. We should mention that, in the last ten years, no other scientific research in the field of Audit in Slovenia has been carried out, apart from the research: of the determinants of voluntary audit Committee formation in a two-tier board system of a post-transitional economy by authors of the audit market concentration for the segments of listed and non-listed auditees; audit fees in 2016; and the impact of the new EU audit regulation. In line with this observation, there are at least three reasons for choosing Slovenia as a relatively new EU country for our research.
\end{abstract}

Keywords: Economies; Financial statements; Research; Market; Quality; Database

\section{Introduction}

The first reason is that there is no article in which are represented comprehensive audit fees for the total audit market in Slovenia [1-4]. Čokelc and Štager researched audit fees for the period 2008-2014 on a sample of 941 audited Annual Reports; because Slovenia is so small an audit market, our research covers all audited Annual Reports, which makes it significantly different from the prior research by authors Cokelc and Stager [4]. The second reason is that no comprehensive research has been performed to show features of audit fees in Slovenia for the period 2009-2015. The third reason is that, although the audit fees are determined in the EU market, identified audit fees and movements between different audit companies (the Big 4 and other small audit companies), can be useful for other similar economies and EU regulators when preparing European audit legislation. Audits are carried out currently by 189 registered Certified Auditors employed in 51 audit firms (as of May 2017). All of the Big 4 audit firms entered the Slovenian audit market shortly after the adoption of the first Auditing Act in 1993.

In the paper, we analyze the audit fees in Slovenia for the period 2009-2015, because the new Auditing Act (2008) required mandatory auditing of financial statements of all large and medium-sized companies, dual companies, small listed companies, companies preparing consolidated Financial Statements, as well as banks and insurance companies. The aim of the research is to determine if the audit fees are statistically significantly different between the audit companies and vary, depending on the size of the non-listed auditees. Similar to other EU Member States, Slovenia is currently undergoing the process of reconciling the Act on Auditing with the new EU Regulation and Directive. Our research of audit fees for the period 2009-2015 is between the last change of the Auditing Act (2008) and the new, expected in 2017 (is currently in Parliament for the third reading). In our research, we investigated the movement of audit fees in relation to the size of the client and the auditing firm. The main research question was: Does the audit fee vary statistically significantly differently between the audit firms? The research question was based on the following hypotheses: Hypothesis 1) Average audit fees in Slovenia differ statistically significantly depending on the auditing firm; Hypothesis 2) Average audit fees in Slovenia vary statistically significantly depending on the size of the client; Hypothesis 3) The Big 4 auditing companies (KPMG,
E\&Y, Deloitte and PwC) were statistically significantly more likely to charge higher audit fees than charged by a small auditing company.

The article is structured as follows. After introduction in Section 1, we present in Section 2 literature review and theoretical background and summarize the findings of some recent researches in the area of audit fees. Section 3 represents hypothesis, methodology and database. The Empirical Section 4 is devoted to the presentation of empirical results of our research, separately for each of three selected hypotheses. Section 5 represents results of our own research of audit fees in Slovenia, along with the results of the analysis and comparative analysis with results of previous researches. In Section 6 we represent conclusion remarks and suggested areas for future research.

\section{Literature Review and Theoretical Background}

Previous research suggests that, in terms of prices of audit services, were investigated: the correlation between audit fees and audit quality audit [5-10], movements of audit fees, depending on the selected factors such as the size of the audit company and the client $[9,10,11$ 16] correlation between audit quality and size of audit company $[17,18]$, correlation between audit fees and competition between audit companies $[13,19]$ the trend of audit fees and their reasons for the increase [20] the degree of industry specialization [10] audit market concentration $[21,22]$.

The research confirmed the positive correlation between audit fee and quality of audit services [6-10]. Asthana and Boone [8] with research, confirmed that the quality of audit services changes when the audit fee deviates from the normal (normative) level; lowering or raising the audit fee affects the quality of auditing, and lowering the audit fee decreases the quality of auditing.

${ }^{*}$ Corresponding author: Stager V, Faculty of Economics and Business, University of Maribor, Maribor, Slovenia, Tel: +38622355280; E-mail: vesna.stager@student.um.si

Received October 10, 2017; Accepted November 13, 2017; Published November 20, 2017

Citation: Stager V, Odar M (2017) Audit Fees for the Segments of Non-Listed Auditees in Slovenia. J Glob Econ 5: 270. doi: 10.4172/2375-4389.1000270

Copyright: ( 2017 Stager V, et al. This is an open-access article distributed under the terms of the Creative Commons Attribution License, which permits unrestricted use, distribution, and reproduction in any medium, provided the original author and source are credited. 
The research ${ }^{1}$ by Simunic [11] provides evidence of the following observations: The largest auditing company does not have a monopoly in the market of audit services; there is a strong correlation between the size of the audit company and the audit fee, and even between large audit firms there is strong competition. At the same time, the author confirmed the existence of greater competition in the market of small clients rather than on the market of large clients because of the existence of a large number of audit firms. Francis and Simon [12], with their research ${ }^{2}$, confirmed that the audit group Big 8 (Big 4 today; Price Waterhouse Cooper, KPMG, Deloitte and Ernst, and Young) for the audit of public limited liability companies charge an additional premium, and that the audit fee of the initial auditing is lower than the already-established business (the new audit fee when changing the auditor). Anderson and Zeghal [13], with research, confirmed that the majority of clients use the services of large-sized audit firms (Big 4) which indicates the lack of competitiveness of audit fee; by contrast, in the audit market, there is competition between small audit firms. Francis et al. [10] have researched the correlation between the size of the audit company, the level of industry specialization and the audit fee. The research confirmed that the audit companies that met both conditions (size and specialization) charge an additional premium of 19\%; audit companies who meet only one condition, do not charge an additional premium. So, the quality of auditing, in addition to the size of the audit company, also provides for sector specialization, which affects the audit fee significantly [10].

Hassan and Naser [9] confirmed by research, that the large company audits stand out, so they are more likely than small auditing companies, subject to pressure, to reduce audit fees. They are trying to justify their existence by improving audit quality and specialization for specific areas of auditing. The authors of the research confirmed that the reputation and status of the auditing company, which is typical for large audit companies, has a major impact on the audit fee. According to a research by Financial Executives Research Foundation - FERF, it was found for the years 2013 and 2014, that the average audit fee ${ }^{4}$ to companies with centralized operations (listed or unlisted) are lower than in companies with decentralized operations. The research showed that companies listed on the Stock Exchange have the same auditing firm on average for 23 years, which is almost three times more than companies that are not listed and non-profit organizations, which have the same auditing firm for eight years on average. $91 \%$ of listed companies are audited by one of the Big 4 audit companies Ernst and Young (13.8\%), PwC (10.5\%), KPMG (9.8\%), Deloitte (9.1\%) [14]. Cullinan and $\mathrm{Du}[15]$ confirmed by research that the maximum audit fees are charged by the Big 4 auditing firms and they withdraw more quickly from clients than small audit firms. With the resignation of the Big 4 audit firms, it is more likely that a small audit firm would replace them.

${ }^{1}$ Simunic (1980) research conducted on a sample of 397 corporations in the United States.

${ }^{2}$ Francis \& Simon (1987) research was conducted on a sample of companies whose securities are listed on the Stock Exchange in the US.

${ }^{3}$ Big-sized audit firms charge lower audit fees because of economies of scale, as it can disperse the fixed costs due to the increased number of clients, which smal auditing company with fewer clients are unable to do (Anderson \& Zeghal, 1994, p. 197)

${ }^{4}$ Average audit fee of the Financial Statements for the year 2013 amounted to 3.9 million USD for companies listed on the Stock Exchange with centralized operations; 9 million USD for companies with decentralized operations; 145,500 USD for companies that are not listed with the centralized operations; 474,000 USD for private companies with decentralized operations (Accounting, 2015).
The authors confirmed by researches that the Big 4 audit firms achieve higher audit fees than small audit firms [9-15]. The research by Le Vourch and Morand [16] provide evidence of low audit fees in Slovenia. The authors investigated and compared audit fees charged to auditees included in Member States' main indices. To tackle the problem of different auditee sizes and enable comparison between countries, the authors introduced variable "audit fees per million turnover". The analysis revealed that, among all EU Member States, audit fees were lowest in Poland (214 EUR per million turnover), followed by Slovenia (267 EUR per million turnover). The highest audit fees for this segment of companies were reported for Belgium (792 EUR per million turnover) and Ireland (739 EUR per million turnover).

The research, confirmed that the audit quality depends on the ability of an auditing company that discovers irregularities in the awarding entity's accounting system and the auditor's independence, which is reflected in the reporting of detected irregularities [17]. Also, the research confirmed that the audit quality of large audit firms is better due to a higher level of competence of employees and its desire to maintain a high reputation [17]. Palmrose [18], as Simunic [11], with research, confirmed that there is a positive correlation between the audit fee and size of audit companies, mainly due to the increased market power of the auditing company and the quality of auditing. The research confirmed that the major auditing companies (Big 4) set audit fees that are higher because of charging additional premiums. In addition, the specialization of the audit company for a particular industry or field of auditing, increases their market share in the industry, because the clients choose a specialized auditing company [18].

The research of the period 1977-1981, confirmed the correlation between the audit fee and the competition between audit companies [19]. In the observed period there were a slightly increased number of clients which, therefore, excluded the possibility of falling audit fees in order to reduce the number of clients. Despite the large number of clients, they have confirmed a significant fall in audit fees. This is explained by the existence of competition among audit firms which, for obtaining a larger market share in the market, reduce the audit fees. Menon and Williams [20] researched the trend of audit fees and the reasons for their increase for the period 1980-1997. In the meantime, there has been a major merger of big auditing firms, which resulted in a reduction in the cost of auditing companies and, consequently, the reduction of audit fees. The authors of the study confirmed the shortterm impact of the merger of audit firms on audit fees, as these resulted in lower prices for three years [20]. Evans and Schwartz [21] with research confirmed that, in the case of US Publicly Traded Companies for the period 2000 to 2010, more regulation increases the fixed costs of the audit, while an increase in audit market concentration does not increase the audit fees.

The research, confirmed that the audit market in most countries is oligopolistic, and dominated by the Big 4 audit companies. Therefore, European countries are concerned that small and medium-sized audit firms will eventually be forced to leave the audit market. This was pointed out in 2011 by the European Commission which, because of its assessment of the market situation, is worrying about audit services [22]. The authors also note that the audit market concentration in the period 1980-2008 increased in most countries; the most prominent are EU Member States, which confirmed the strong oligopoly of large audit firms (the Big 4), especially for companies listed on the Stock Exchange [22]. These are audited mainly by the Big 4 auditing companies to the extent of more than $90 \%$. Although a number of medium-sized audit firms showed the ability to audit on international markets, they can 
hardly get a big client. Due to such market concentrations, there can be a buildup of systemic risk and collapse of a systemically important company, or a company that has reached a systemic relevant range, which can cause turbulence in the market as a whole (European Commission 2010, p. 15). Market concentration ${ }^{5}$ is, in some segments of the market, too high, as the clients of audit services prevent greater choice. In this context, the audit of large companies listed on the Stock Exchange, acquired a reputation. The selection of an auditing company is still affected negatively by the fact that the largest companies do not recognize their skills. There are also examples of clauses (e.g., financial institutions) of "Big Four only", which is a condition for the granting of loans (European Commission 2010, p. 16).

Literature review, related to audit fees, shows that, in Slovenia, there is no comprehensive research for the period 2009-2015, so this issue led us to the goal to research in this field. Scientific research in Slovenia have, until now been prepared by the authors Salihovic and Zaman [3] and Cokelc and Stager [4]. We must not ignore the findings of previous professional studies [23-26], which are not scientific in nature but, nevertheless, give important expert input to the selected topic.

For the period 2002-2005, studied the level of competition in the audit market, based on the market power of the company [23]. The survey confirmed the following situation on the Slovenian market of audit services: Audit fees are falling, which increases dependence of audit firms on existing clients ${ }^{6}$; audit companies assume operations to other audit firms by lowering the audit fees; audit fees fluctuate largely independently of the required audit scope and are dependent on the other, the harder measurable market factors; there is weak medium audit market concentration, whereby the concentration indicators in the studied period fall. When auditing medium-sized companies whose securities are not listed on the Stock Market, there is intense competition; in large companies whose securities are listed on the Stock Exchange, there is very strong competition. With this research, the author confirmed that, with the companies whose securities are listed on the Stock Exchange, we can speak of an oligopoly and the weak competitive market of audit services. Among the key findings of the research the author confirmed: The audit fee is a key criterion for the selection of an auditing company; the audit fees in Slovenia do not reflect the extent of the work specified by the value of items in the audited Financial Statements; audit companies acquire business by lowering audit fees; audit fees are falling; financial dependence of audit firms on their clients is large [23].

Komadina [24] with his survey, found that the size of the client

${ }^{5}$ The European Commission (EC, 2010) stated in a Green Paper from the year 2010 , that it would like to examine the possibility of joint audits (audit consortia). Joint audits are carried out only in France, where the company whose shares are quoted on the Stock Exchange are subject to the obligation to appoint two differen audit firms, who share the audit work and sign the report on the Audit of Financial Statements jointly. In order to encourage the growth of small and medium-sized audit firms, the Commission could consider introducing compulsory consortium audit firms with the inclusion of at least one audit company who do not carry out audits of large companies. In establishing these consortia it would take into account the clear division of responsibilities in relation to the joint audit opinion and to determine the mechanism for the resolution/disclosure of differences in the opinions of different members of the consortium. The idea of a "joint audit" is also useful for mitigating disruption in the audit market, in case of failure of the curren audit network (European Commission 2010, p. 16).

${ }^{6}$ The author confirmed by the research that the audit companies in the year 2005 in most cases, took up clients with lower audit fees, which was proved especially when the client was previously audited by the Big 4 and, after that, the audit of the client was taken over by a smaller auditing firm. Acquisitions of entities operating in the opposite direction usually go for a higher audit fee than the previous auditing company (Skitek, 2009, p. 94). affects the audit fee to companies listed on the Stock Exchange because, by increasing the size of client, the audit fees are increasing. The complexity of the client affects the audit fees, as, the more complex a client is, higher the audit fees are. The risks of a client have no affect on the audit fee. The audit fee has an impact on the audit company's status, as an auditing company with high status charges higher audit fees. Slovenian economic activity does not affect the audit fee, so we cannot say that the audit fee falling during the economic and financial crisis. Even the first relationship between the client and the audit firm does not affect the audit fee, because the audit fees in the first year of the audit were not different. Pavlic [25] with his survey ${ }^{7}$ of audit fees in the Slovenian traded companies, found that the audit fee from the previous period has strong influence on the audit fee in the current period, while other variables remain unchanged. The author explains that the reason for the negative correlation is in the fact that clients with a high profit rate have lower audit risk than clients that show a loss, since the loss of the client is usually also correlated with aggressive tax planning and poorer quality of internal controls.

Salihovic and Zaman [3], with their research, found that the ten largest audit companies controlled almost the entire market (86.1\%). Coefficients of concentrations in the observed period grew constantly, except in 2010, when they declined because of the falling revenues of KPMG, which had, among all market participants, the highest market share. The largest four auditing companies employ more than half of the employees in the audit market. Audit companies from the Big 4 audited $43.6 \%$ of clients. The ten largest audit firms, on average, audited $90.7 \%$ of clients [3].

Cokelc and Stager [4] have researched on a sample the movements of audit fees, depending on the size of the client, the size of the audit company and influence of changing the auditor to audit fee. The research found that the average fees in Slovenia are statistically significantly different from the normative audit fee, depending on the size of the client; the Big 4 audit firms (KPMG, E\&Y, Deloitte and $\mathrm{PwC}$ ) statistically significantly billed normative audit fees more frequently, than charged by a small auditing company; small clients, when changing audit companies, achieve lower audit fees, but were not statistically significant. Medium and large clients, when changing audit firms, achieved, on average, higher audit fees, but were not statistically significant [26].

A literature review indicates that, for Slovenia, a comprehensive research of audit fee movements for 2009-2015 has not yet been carried out, so we carried out such a research and compared it with the findings of previous research in the world [3,4,16,23-25].

\section{Hypothesis, Methodology and Database}

\section{Hypothesis}

In our research, we investigated the movement of audit fees in relation to the size of the client and the auditing firm. The main research question was: Does the audit fee vary statistically significantly

${ }^{7}$ With an increase in revenue by 1 EUR, the audit fee will rise, on average, by 5.78 $\times 10-6$, so the author confirmed that the increase in client revenue may affect the growth of audit fees. With an increase in the number of subsidiaries by 1 company the audit fee, on average, increased by 218.3 EUR; in the event of an increase in net profit by 1 EUR, the audit fee will show an average decrease of 0.000065 EUR (Pavlič, 2015, p. 47). Pavlič (2015), with the study, could not confirm the hypothesis: Positive correlation between the Balance Sheet total of the client and the audit fee; the size of the audit company has a positive impact on the audit fee; replacement of an auditor has impact on the audit fee; an unqualified auditor's opinion affects the audit fee negatively. 
differently between the audit firms? The research question was based on the following hypotheses:

Hypothesis 1: Average audit fees in Slovenia differ statistically significantly depending on the auditing firm.

Hypothesis 2: Average audit fees in Slovenia vary statistically significantly depending on the size of the client.

Hypothesis 3: The Big 4 auditing companies (KPMG, E\&Y, Deloitte and $\mathrm{PwC}$ ) were statistically significantly more likely to charge higher audit fees than charged by a small auditing company.

The study was performed on all companies (no limitation) that submitted Audited Financial Statements to the Statistical Office of Slovenia and revealed the audit price in the Annual Report. Financial Institutions (banks, insurance companies, state public institutions) were excluded from our research. A second limitation is that, in our study, were included all companies with Annual Report and consolidated Annual Report audited by the auditing company. In addition, the researcher has no assurance as to whether the audit fees revealed in Annual Report are accurate. Additional research will be needed to determine if the findings hold for Financial Institutions audited by the Big 4 .

\section{Methodology and database}

For the purpose of the research, we collected information of the audit prices for 2009-2015 with insight to Annual Reports submitted to AJPES. Based on these data, we included in our research 16,591 Annual Reports which were submitted in the period 2009-2015 to AJPES and had disclosed the audit price. Audited Annual Reports are sorted by the audit company, namely: 1,596 (9.6\%), KPMG; 1,078 (6.5\%) E\&Y; 1,596 (9.6\%) Deloitte; 757 (4.6\%) PWC; 10,221 (61.6\%) Small AC. The research covers $14,508(87.40 \%)$ of the audited Annual Reports and $1,756(11.80 \%)$ of the audited Consolidated Annual Reports. Financial Institutions and other agreed-upon procedures were excluded from the research. We examined at least 89 Annual Reports for each audit firm in each studied year. Audit clients are divided into small, medium and large. The research included: 5,150 (31.0\%) large; 5,464 (32.9\%) medium; 5,169 (31.2\%) small audit clients; for 808 (4.9\%) audit clients the size was not calculated. The survey covered all auditing companies in Slovenia, which we divided in two groups: The Big 4 (KPMG, E\&Y, Deloitte, PwC) and all the small auditing companies (Small AC).

We provided a specific survey homogeneous population-all companies in Slovenia that submitted Financial Statements to the
Statistical Office of Slovenia. The collected data was analyzed with SPSS software, a descriptive analysis of the variables and one-way analysis of variance (One-way ANOVA) was used to test the hypotheses. The significance level was set to 0.05 (5\%). As the first step of our analysis, we examined the descriptive statistics of the analyzed variables. Then we carried out our verification of the hypothesis, separately for small, middle and big sized companies, and also with regard to the auditing company. To test if the variables are featured by normal distribution in the analyzed period we used Kolmogorov-Smirnov tests; audit fee $(\mathrm{D}=.422, \mathrm{p}=.000)$ as shown in Figure 1.

\section{Results and Discussion}

\section{Results for verifying Hypothesis 1}

To verify Hypothesis 1, are the average audit prices in Slovenia significantly different depending on the auditing company, we used descriptive statistics and a parametric T-test. We compared the audit prices to audit company: KPMG, E\&Y, Deloitte, PwC and groups of small auditing companies (Small AC). Researched data were also classified according to the size of the client (Table 1). We examined whether there are statistically significant differences in the audit prices to audit companies groups (Table 2). We also used the Kruskal-Wallis test (Figure 2).

To check that the distribution of audit prices is approximately normal, we need to look at the values of skewness and kurtosis (Table 1). Positive values of skewness indicate too many low scores in the distribution. The values of skewness are more than zero, so the data are distributed asymetrically right. Positive values of kurtosis indicate a pointy and heavy-tailed distribution. The values of kurtosis are more than zero, so the data are distributed pointed.

Levene's Test for Equality of Variances (Table 1), with less than 5\% of the risk it can be assumed that there were no statistically significant differences in audit prices among groups ( $>00.05)$ : KPMG and $E \& Y$ $(\mathrm{p}=.001)$; KPMG and Deloitte $(\mathrm{p}=.747)$; KPMG and PwC $(\mathrm{p}=.002)$; Deloitte and $\mathrm{PwC}(\mathrm{p}=.300)$. Statistically significant differences in audit prices are among groups $(\mathrm{p}<0.05)$ : KPMG and Small AC, E\&Y and Small AC, Deloitte and Small AC, PwC and Small AC, E\&Y and PwC. This confirms the value of the $\mathrm{t}$-test for an arithmetic mean of audit price which is explained in Figure 2.

The Kruskal-Wallis test shows that audit prices were affected significantly by the audit company, $\mathrm{H}(4)=1,528, \mathrm{p}=000 \quad(\mathrm{p}>.05)$. Hypothesis 1, the average audit price in Slovenia differs significantly depending on the auditing company, can be confirmed.
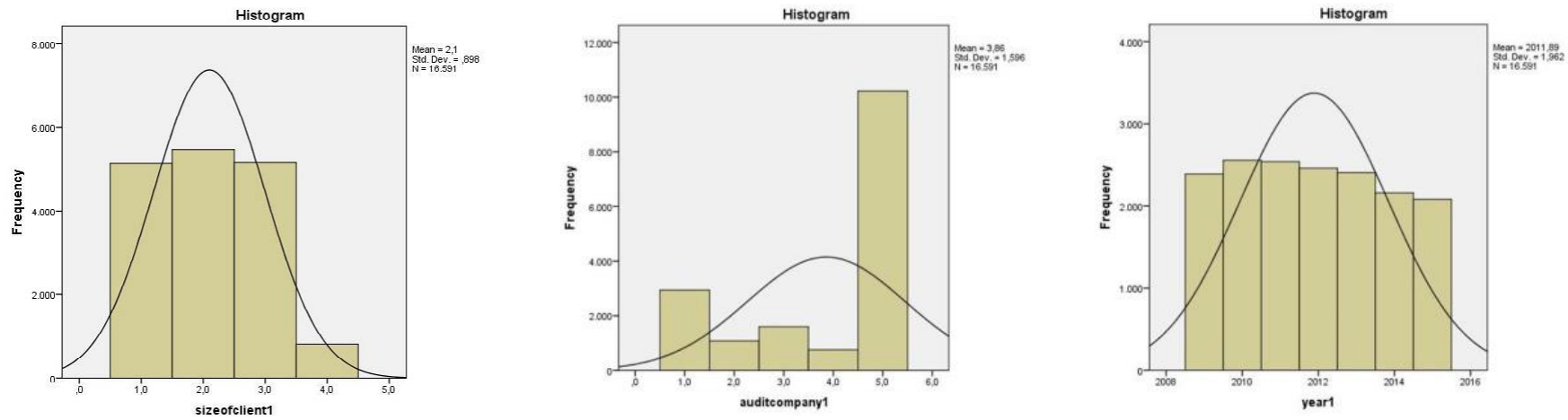

Source: Authors calculations, extracted from SPSS

Figure 1: Histogram of size of client, audit companies and researched years. 
Citation: Stager V, Odar M (2017) Audit Fees for the Segments of Non-Listed Auditees in Slovenia. J Glob Econ 5: 270. doi: 10.4172/23754389.1000270

Page 5 of 8

\begin{tabular}{|c|c|c|c|c|c|c|c|}
\hline Audit company & Size of client & Mean & $\mathbf{N}$ & Std. Deviation & Std. Error of Mean & Kurtosis & Skewness \\
\hline \multirow[t]{5}{*}{ Deloitte } & Large & 19,315 & 804 & 48,066 & 1,695 & 142 & 11 \\
\hline & Middle & 9,700 & 386 & 5,043 & 257 & 2 & 1 \\
\hline & Small & 7,486 & 370 & 26,189 & 1,362 & 341 & 18 \\
\hline & $\mathrm{NC}$ & 13,592 & 36 & 18,212 & 3,035 & 3 & 2 \\
\hline & Total & 14,118 & 1,596 & 36,929 & 924 & 232 & 14 \\
\hline \multirow[t]{5}{*}{ E\&Y } & Large & 27,463 & 500 & 41,770 & 1,868 & 84 & 8 \\
\hline & Middle & 15,378 & 306 & 55,952 & 3,199 & 147 & 12 \\
\hline & Small & 6,551 & 270 & 4,280 & 261 & 15 & 3 \\
\hline & NC & 7,300 & 2 & 2,404 & 1,700 & - & - \\
\hline & Total & 18,757 & 1,078 & 42,137 & 1,283 & 166 & 12 \\
\hline \multirow[t]{5}{*}{ KPMG } & Large & 17,089 & 1,053 & 18,483 & 570 & 15 & 3 \\
\hline & Middle & 10,461 & 691 & 28,446 & 1,082 & 261 & 16 \\
\hline & Small & 11,319 & 985 & 62,544 & 1,993 & 152 & 12 \\
\hline & NC & 9,065 & 210 & 16,523 & 1,140 & 88 & 8 \\
\hline & Total & 13,024 & 2,939 & 40,639 & 750 & 300 & 16 \\
\hline \multirow[t]{5}{*}{ PwC } & Large & 21,840 & 281 & 26,445 & 1,578 & 19 & 4 \\
\hline & Middle & 13,646 & 232 & 10,161 & 667 & 62 & 6 \\
\hline & Small & 9,840 & 230 & 7,090 & 467 & 13 & 3 \\
\hline & NC & 9,693 & 14 & 5,555 & 1,484 & -2 & -0.028 \\
\hline & Total & 15,458 & 757 & 18,240 & 663 & 40 & 5 \\
\hline \multirow[t]{5}{*}{ Small AC } & Large & 51,192 & 2,512 & 170,759 & 3,407 & 14 & 4 \\
\hline & Middle & 9,149 & 3,849 & 46,646 & 752 & 285 & 17 \\
\hline & Small & 23,012 & 3,314 & 115,285 & 2,003 & 39 & 6 \\
\hline & NC & 24,512 & 546 & 116,188 & 4,972 & 44 & 6 \\
\hline & Total & 24,797 & 10,221 & 115,222 & 1,140 & 39 & 6 \\
\hline
\end{tabular}

Note: NC: Not calculated.

Table 1: The prices of audit services, depending on the client and the audit company for the period 2009-2015.

Audit Group

KPMG and Small AC

E\&Y and Small AC

Deloitte and Small AC

PWC and Small AC

KPMG and E\&Y

KPMG and Deloitte

KPMG and PwC

E\&Y and Deloitte

E\&Y and PwC

Deloitte and PwC

Source: Authors' calculations, extracted from SPSS

\begin{tabular}{|c|c|c|c|}
\hline $\mathbf{F}$ & $\mathbf{t}$ & $\mathbf{d f}$ & $\boldsymbol{p}$ \\
\hline 160.963 & -8.631 & $12.704,415$ & .000 \\
\hline 40.189 & -3.519 & $3.233,560$ & .000 \\
\hline 86.619 & -7.277 & $7.444,858$ & .000 \\
\hline 46.314 & -7.084 & $7.185,509$ & .000 \\
\hline 11.830 & -3.923 & 4.015 & .001 \\
\hline .104 & -.894 & 4.539 & .747 \\
\hline .480 & -1.607 & 3.694 & .488 \\
\hline 9.257 & 3.009 & 2.672 & .002 \\
\hline 15.016 & 2.284 & $1.569,261$ & .000 \\
\hline 1.075 & -.945 & 2.351 & .300 \\
\hline
\end{tabular}

Table 2: Independent sample test - levene's test for equality of variances.

Independent-Samples Median Test

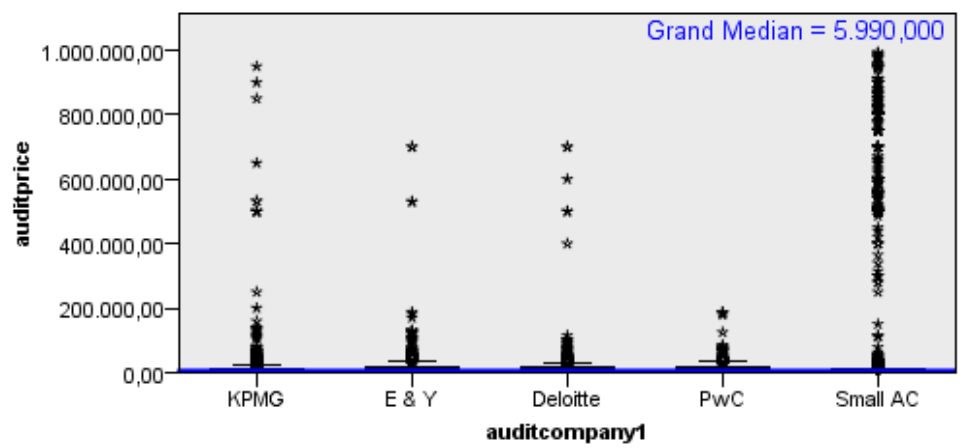

Source: Authors calculations, extracted from SPSS.

Figure 2: Kruskal-Wallis test. 


\section{Results for verifying Hypothesis 2}

To verify Hypothesis 2, that the average audit prices in Slovenia differ significantly depending on the client, we used descriptive statistics and a parametric T-test. Clients of audit services are divided according to size into three categories (small, medium, large) and compared to the average audit price of audit companies KPMG, E\&Y, Deloitte, PwC and the group of small auditing companies (Tables 2 and 3 ).

Levene's Test for Equality of Variances (Table 3) show that, with less than $5 \%$ of the risk, it can be assumed that there were no statistically significant differences in audit prices among the group "middle and small" client ( $>0.05)$, if they are audited by: KPMG $(\mathrm{p}=.0 .27) ; \mathrm{E} \& \mathrm{Y}(\mathrm{p}=.022) ;$ Deloitte $(\mathrm{p}=.261) ; \mathrm{PwC}(\mathrm{p}=.011)$. Also, there were no statistically significant differences in audit prices among the group "large and small" clients ( $\mathrm{p}>0.05$ ), if they are audited by: KPMG ( $\mathrm{p}=.0 .898)$; and among the group "large and middle" client $(\mathrm{p}>0.05)$, if they are audited by E\&Y ( $\mathrm{p}=.0 .001)$. Statistical significant differences in audit prices among the group "middle and small" clients are $(\mathrm{p}<0.05)$, if they are audited by Small AC; among the "group" large and "small" clients $(p<0.05)$, if they are audited by E\&Y, Deloitte, PwC and Small $\mathrm{AC}$; among the "group" "large and middle" clients $(\mathrm{p}<0.05)$, if they are audited by: KPMG, Deloitte, PwC and Small AC. This confirms the value of the $\mathrm{t}$-test for an arithmetic mean of audit price.

Hypothesis 2, that the average audit prices in Slovenia vary significantly depending on the size of the client, may be partially confirmed. This assumption is true in the case when a group of small auditing company (Small AC) audited medium and small clients; E\&Y, Deloitte, PwC and Small AC audited large and small clients; KPMG, Deloitte, PwC and Small AC audited large and middle clients. The hypothesis was not confirmed in part when auditing services of small and medium sized clients are performed by KPMG, E\&Y, Deloitte or
PwC; large and small sized clients are performed by KPMG; large and middle clients are performed by E\&Y.

\section{Results for verifying Hypothesis 3}

In order to check Hypothesis 3, that large audit companies (the Big 4: KPMG, E\&Y, Deloitte and PWC) statistically significantly charge higher audit prices more often than are charged by the small audit company (Small AC), we used descriptive statistics and the parametric T-test. Audit companies were divided into two groups (Big 4 and Small $\mathrm{AC})$, so we compared the average audit prices between the groups (Table 4). Graphically, we present the trend of average audit prices and trends in the audit companies for 2009-2015).

Levene's Test for Equality of Variances shows that the distribution of average audit prices, which are determined by Big 4 and Small AC, shows that there were statistically significant differences $(\mathrm{F}=315.478$; $\mathrm{p}<0.05)$. This confirms the value of the t-test for an arithmetic mean of audit prices because, between Big 4 and Small AC, there were statistically significant differences in audit prices $(\mathrm{t}=-8.289, \mathrm{df}=13,447.848, \mathrm{p}=.000)$.

Figures 3 and 4 show that the median of audit price of Deloitte, KPMG and small auditing company (Small AC) are falling. Hypothesis 3, that large auditing companies (Big 4: KPMG, E\&Y, Deloitte and $\mathrm{PwC}$ ) were statistically significantly more likely to charge higher audit prices than a small auditing company (Small AC) charges, can be confirmed.

The results of our research are comparable with previous researches $[9-13,15]$ which confirmed that the Big 4 audit firms achieve higher audit fees than small audit firms; this is confirmed on the basis of calculation of median of the audit fees (Table 5) through years and audit companies.

\begin{tabular}{|c|c|c|c|c|}
\hline Audit company & $\mathbf{F}$ & $\mathbf{t}$ & df & $p$ \\
\hline \multicolumn{5}{|c|}{ Middle and Small Client } \\
\hline KPMG & 4.892 & -.337 & 1.674 & .027 \\
\hline E\&Y & 5.313 & 2.585 & 574 & .022 \\
\hline Deloitte & 1.265 & 1.630 & 754 & .261 \\
\hline PwC & 6.495 & 4.666 & 460 & .011 \\
\hline Small AC & 244.621 & -6.481 & $4.240,268$ & .000 \\
\hline \multicolumn{5}{|c|}{ Large and Small Client } \\
\hline KPMG & .016 & 2.863 & 2.036 & .898 \\
\hline E\&Y & 66.353 & 11.087 & 518.234 & .000 \\
\hline Deloitte & 16.780 & 5.441 & $1.140,426$ & .000 \\
\hline PwC & 66.424 & 7.293 & 328.247 & .000 \\
\hline Small AC & 167.756 & 7.130 & $4.168,689$ & .000 \\
\hline \multicolumn{5}{|c|}{ Large and Middle Client } \\
\hline KPMG & 32.689 & 5.420 & $1.071,354$ & .000 \\
\hline E\&Y & 10.180 & 3.494 & 804 & .001 \\
\hline Deloitte & 26.146 & 5.608 & 839.324 & .000 \\
\hline PwC & 46.296 & 4.784 & 374.572 & .000 \\
\hline Small AC & 821.667 & 12.050 & $2.757,263$ & .000 \\
\hline
\end{tabular}

Table 3: Independent sample test - Levene's test for equality of variances.

\begin{tabular}{|c|c|c|c|c|}
\hline Audit Group & $\mathbf{N}$ & Mean & Std. Deviation & Std. Error Mean \\
\hline Big 4 & 6,370 & 14,557 & 38,044 & 476.664 \\
\hline Small AC & 10,221 & 24,794 & 115,222 & $1,139.699$ \\
\hline
\end{tabular}

Source: Authors' calculations, extracted from SPSS.

Table 4: Group Statistics. 


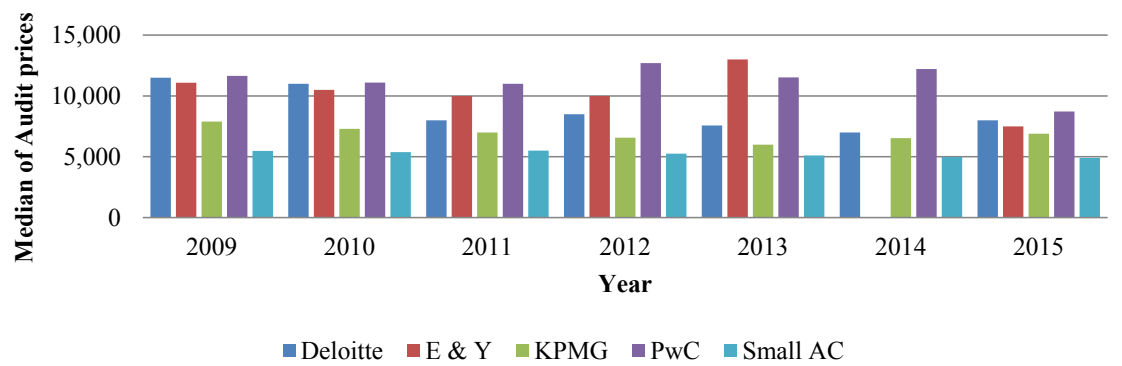

Source: Authors calculations.

Figure 3: Movement of median of audit prices for the period 2009-2015.

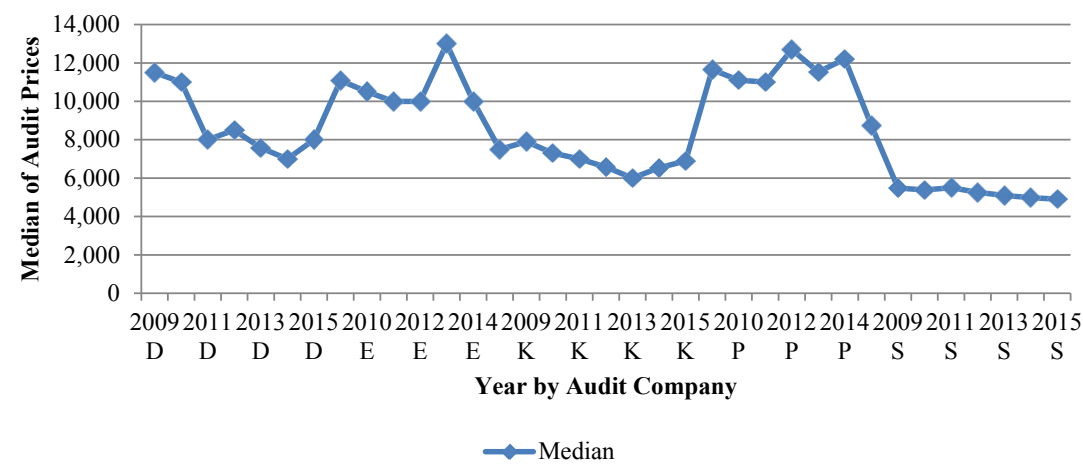

Source: Authors calculations.

Figure 4: Trend of median of audit prices for the period 2009-2015 by audit company.

\begin{tabular}{|c|c|c|c|c|c|c|c|}
\hline & 2009 & 2010 & 2011 & 2012 & 2013 & 2014 & 2015 \\
\hline Deloitte & 11,500 & 11,000 & 8,000 & 8,500 & 7,575 & 7,000 & 8,000 \\
\hline$E \& Y$ & 11,095 & 10,500 & 10,000 & 10,000 & 12,997 & 10,000 & 7,500 \\
\hline KPMG & 7,900 & 7,300 & 7,000 & 6,576 & 6,000 & 6,538 & 6,895 \\
\hline PwC & 11,650 & 11,100 & 11,000 & 12,700 & 11,528 & 12,210 & 8,725 \\
\hline Small AC & 5,486 & 5,381 & 5,500 & 5,260 & 5,100 & 4,983 & 4,900 \\
\hline Total & 6,230 & 6,000 & 6,000 & 6,000 & 5,737 & 5,587 & 5,606 \\
\hline
\end{tabular}

Table 5: Median of the audit fees.

\section{Results and Discussion}

The results of our research reveal that the segment of non-listed companies in Slovenia does face falling audit fees; a large number of auditees are audited by a large number of small audit firms, each of them holding a small market share. In Slovenia no auditing company has dominant influence; also, the Big 4 auditing companies do not have a dominant market share. Considering the period of 2009-2015, we recognize the trend of continued falling of audit fees (32\% E\&Y; 30\% Deloitte; 25\% PwC; 13\% KPMG; 10\% small auditing companies). The low fluctuating of audit fees through the period 2009-2015 is recognized only for small auditing companies.

We find, like Simunic [11], that the largest auditing companies do not have a monopoly in the market of audit services; there is a strong correlation between the size of the audit company and the audit fee, and even between large audit firms there is strong competition. Our findings are not consistent with those of the authors Anderson and Zeghal [13] that the majority of clients use services of large-sized audit firms (Big 4), which indicates the lack of competitiveness of audit fees; Slovenia is characterized by the following proportions: $1,596(9.6 \%)$,
KPMG; 1,078 (6.5\%) E\&Y; 1,596 (9.6\%) Deloitte; 757 (4.6\%) PWC; 10,221 (61.6\%) Small AC. We confirm, like Anderson and Zeghal [13] that, in the audit market, there is competition between small audit firms.

We find also, like Cullinan and $\mathrm{Du}[15]$ that, with the resignation of Big 4 audit firms, it is more likely that the audit would be carried out by a small audit firm. We confirm that there is a positive correlation between the audit fee and size of audit companies, as was confirmed with previous research by Palmrose [18] and Simunic [11]. Despite the number of clients, we confirm the fall in audit fees, like Maher et al. [19] this is explained by the existence of competition among audit firms which, for obtaining a larger market share in the market, reduce the audit fees. Velte and Stiglbauer [22] find that companies listed on the Stock Exchange are audited by the Big 4 auditing companies to the extent of more than $90 \%$. From our research were excluded companies listed on the Stock Exchange but, by reviewing the Annual Reports of these companies, we find out that these are audited $100 \%$ by the Big 4 audit companies; like Velte and Stiglbauer [22], we confirm that the medium-sized audit firms can hardly get a big client. Due to such market concentrations, there can be a build up of systemic risk and 
collapse of a systemically important company, or a company that has reached a systemic relevant range, which can cause turbulence in the Slovenian audit market as a whole, as recalls the European Commission (2010).

The findings of our research are consistent with previous research of the Slovenian market: Audit fees are falling $[4,23]$ audit companies acquire business by lowering audit fees $[4,23]$ companies listed on the Stock Exchange are audited by the Big 4 auditing companies $[4,23,24]$ the Big 4 audit companies audited $38.4 \%$ of clients [3] found out $43.6 \%$.

\section{Conclusions}

The results of our research show that the average audit price in Slovenia differs significantly depending on the auditing company, so the Hypothesis 1 is confirmed. The average audit prices in Slovenia vary significantly depending on the size of the client. This assumption is true in the case when a group of small auditing company (Small AC) audited medium and small clients; E\&Y, Deloitte, PwC and Small AC audited large and small clients; KPMG, Deloitte, PwC and Small AC audited large and middle clients. The Hypothesis 2 was not confirmed in part when auditing services of small and medium sized clients are performed by KPMG, E\&Y, Deloitte or PwC; large and small sized clients are performed by KPMG; large and middle clients are performed by E\&Y. The large auditing companies (Big 4: KPMG, E\&Y, Deloitte and $\mathrm{PwC}$ ) were statistically significantly more likely to charge higher audit prices than a small auditing company (Small AC) charges, so the Hypothesis 3 is confirmed. Based on a careful examination of the issues addressed, we find that, until now, a comprehensive research of audit fees has not been carried out in Slovenia, so this represents a significant contribution to science. Research is between different periods, so the future research, after adoption of the new Auditing Act (expected in 2017) will show if there is any impact of the new regulation on audit fees. Beyond the audit fees, related evidence provided by our research, regulators and policymakers should also consider the available empirical evidence dealing with the effects of the new Auditing Act on audit fees and, consequently, audit quality, to address these highly relevant topics properly in the national legislation. Future research should examine the determinants of audit quality in correlation with audit fees carefully. Based on our empirical research, it is possible to carry out extensive quantitative research, therefore, a contribution to science seen in the quantitative research, which also includes other variables of audity quality for all auditees and correlation to the expected requirements of the new Auditing Act, and also in comparison with other EU countries. The proposed research is unique, since a similar research in Slovenia has not yet been carried out and our findings are original.

\section{References}

1. Ramzy WAM (1988) The Determinants of Audit Fees - An Analytical Study Watt University.

2. Zaman GM, Valentincic A (2011) Determinants of Voluntary Audit Committee Formation in a Two-Tier Board System of a Post-transitional Economy-The Case of Slovenia. Accounting in Europe 8: 235-256.
3. Salihovic A, Zaman GM (2015) Analysis of Price Factors for audit services in Slovenia. Sirius (1): 38-56.

4. Cokelc S, Stager V (2016) Prices of audit services. Sirius 2: 40-77.

5. Duhovnik M (2016) This is not America: The Impact of the New EU Audit Regulation in Slovenia. Economic and Business Review 18: 227-246.

6. Barragato CA, Markelevich A (2008) Earnings quality following corporate acquisitions. Managerial Finance 34: 304-315.

7. Choi J, Kim C, Zang Y, Kim J (2010) Audit office size, audit quality and audit pricing. Auditing 29: 73-97.

8. Asthana SC, Boone JP (2012) Abnormal Audit Fee and Audit Quality. A Journal of Practice and Theory 31: 1-22.

9. Hassan YM, Naser K (2013) Determinants of audit fees: Evidence from an emerging economy. International Business Research 6: 13-25.

10. Francis JR, Reichelt K, Wang D (2005) The Pricing of National and City-specific reputations for Industry Expertise in the U.S. Audit Markets. The Accounting Review 80: 113-136

11. Simunic DA (1980) The pricing of audit services: theory and evidence. Journal of Accounting Research 18: 161-190.

12. Francis JR, Simon DT (1987) A test of audit pricing in the small-client segmentation of the U.S. audit market. The Accounting Review 62: 145-157.

13. Anderson T, Zeghal D (1994) The pricing of audit services: Further evidence from the Canadian market. Accounting and Business Research 24: 195-206.

14. Accounting (2015) Survey: Public and Private Company Audit Fees Went Up in 2013.

15. Cullinan CP, Du H (2010) Big 4, Next 4, and Smaller Accounting Firms: Resignations v. Dismissals and the Outcome of the Auditor Change process. Journal of American Academy of Business 16: 58-64.

16. Le Vourch J, Morand P (2011) Study on the effects of the implementation of the acquis on statutory audits of annual and consolidated accounts including the consequences on the audit market. Paris: ESCP Europe.

17. DeAngelo LE (1981) Auditor size and audit quality. Journal of Accounting \& Economics 3: 183-199.

18. Palmrose ZV (1986) Audit fees and auditor size: Further evidence. Journal of Accounting Research 24: 97-110.

19. Maher MW, Tiessen P, Colson R, Broman AJ (1992) Competition and audit fees. The Accounting Review 67: 199-210.

20. Menon K, Williams DD (2001) Long-term trend in audit fees. Auditing. Journa of Practice and Theory 20: 115-136.

21. Evans LJ, Schwartz J (2014) The effect of concentration and regulation o audit fees: An application of panel data techniques. Journal of Empirical Finance 27 130-144.

22. Velte P, Stiglbauer M (2012) Audit Market Concentration and Its Influence on Audit Quality. International Business Research 5: 146-161.

23. Skitek M (2009) Critical consideration of ensuring the financial independence of audit firms in auditing financial statements.

24. Komadina D (2014) Analysis of the factors of the prices of audit services in Slovenia.

25. Pavlic B (2015) Analysis of the prices of auditing of Slovenian non-public joint stock companies.

26. Salihovic A (2014) Analysis of concentration in the market of audit services in Slovenia. 